\title{
Analisis Penerapan Total Productive Maintenance (TPM) Menggunakan Overall Equipment Efectiveness (OEE) Dan Six Big Losses Pada Mesin Cold Leveller PT. KPS
}

\author{
Muhammad Bob Anthony ${ }^{(1)}$ \\ ${ }^{(1)}$ Program Studi Teknik Industri, Fakultas Teknik, Universitas Serang Raya \\ Email : tonipbmti@gmail.com ${ }^{(1)}$
}

\begin{abstract}
Abstrak
PT. KPS adalah salah satu perusahaan baja di Indonesia yang memproduksi produk baja berupa slab dan plate yang dipasarkan di dalam negeri hingga ke luar negeri. Mesin cold leveller merupakan mesin yang berfungsi meratakan permukaan plate yang tidak rata. Permasalahan yang terjadi pada mesin tersebut yaitu sering mengalami breakdown sehingga plate dengan permukaan yang tidak rata semakin banyak karena waktu bekerja mesin semakin berkurang. Penelitian ini bertujuan untuk menghitung nilai overall equipment effectiveness (OEE), menghitung nilai faktor six big losses dan mengetahui akar penyebab masalah yang dominan dari faktor six big losses dengan fishbone diagram. Nilai OEE yang didapat pada mesin cold leveller adalah sebesar $82 \%$. Faktor terbesar yang menyebabkan rendahnya efektifitas mesin yaitu reduced speed losses sebesar 11,59\% dan equipment failure losses sebesar $6,04 \%$. Tindakan perbaikan yang diusulkan adalah memprioritaskan 3 pilar utama TPM yaitu autonomous maintenance, quality maintenance, training dan education.
\end{abstract}

Kata Kunci: fishbone diagram, overall equipment effectiveness (OEE), pareto, six big losses , total productive maintenance (TPM)

\begin{abstract}
PT. KPS is one steel company in Indonesia that produces steel products in the form of slab and plate that is marketed in the country up to foreign countries. Cold leveller machine is a machine that serves to flatten the surface of the plate. Problems occurred in the machinery that is often experienced a breakdown so that the plate with uneven surfaces more and more because of the time machine working on the wane. This research aims to quantify the value of the overall equipment effectiveness (OEE), calculating the factor of six big losses and figure out the root cause of the problem, the dominant factor of the six big losses with the fishbone diagram. The OEE value obtained on the engine cold leveller is $82 \%$. The biggest factor that causes the low effectiveness of the machine that is the reduced speed losses amounting to $11.59 \%$ and equipment failure losses amounted to $6.04 \%$. The proposed corrective actions is prioritizing the main TPM pillar 3 that is autonomous maintenance, quality maintenance, training and education.
\end{abstract}

Keyword : fishbone diagram, overall equipment effectiveness (OEE), pareto, the six big losses, total productive maintenance (TPM) 


\section{Pendahuluan}

PT. KPS adalah salah satu perusahaan yang bergerak di bidang industri pembuatan baja terpadu yang berkualitas tinggi. Pada bagian produksi perusahaan tersebut terdapat 3 departemen utama yaitu iron making department, steel making department dan plate rolling department. Kegiatan produksi dibagian plate rolling departement adalah pengolahan dan pemotongan slab menjadi plate. Dari beberapa ukuran tebal plate yang diproduksi oleh PT. KPS, produk plate dengan ukuran tebal 6-25 mm sering sekali mengalami kecacatan pada flatness-nya sehingga banyak sekali produk plate yang menumpuk karena defect flatness. Cold leveller adalah salah satu fasilitas yang berada di plate rolling department yang berfungsi memperbaiki defect flatness pada plate sebelum dikirim ke customer. Untuk menghindari produk plate pesanan customer tidak mengalami keterlambatan, maka pengiriman produk plate dengan defect flatness harus segera diperbaiki. Permasalahan yang terjadi pada mesin tersebut yaitu sering mengalami breakdown sehingga plate dengan permukaan yang tidak rata semakin banyak karena waktu bekerja mesin semakin berkurang. Untuk mengatasi masalah tersebut diperlukan langkahlangkah yang tepat dalam pemeliharaan mesin atau peralatan, salah satunya dengan melakukan penerapan total productive maintenance (TPM) [1],[2],[3]. TPM sendiri bertujuan untuk tercapainya keidealan kinerja, serta zero loss yang berarti tidak ada cacat, breakdown, kecelakaan, dan kesia-siaan dalam proses baik dalam produksi maupun changeover [4], [3],[5],[6]

Evaluasi penerapan total productive maintenance (TPM) dilakukan dengan menggunakan nilai overall equipment effectiveness (OEE) sebagai indikator serta mencari penyebab ketidakefektifan dari mesin tersebut dengan melakukan perhitungan six big losses untuk mengetahui faktor yang berpengaruh dari keenam faktor six big losses yang ada. Dengan melakukan perhitungan OEE, perusahaan akan mengetahui dimana posisi mereka dan dimana titik kelemahan serta bagaimana cara melakukan perbaikan. Tujuan yang ingin dicapai dalam penelitian ini adalah melakukan analisis dalam penerapan TPM di PT. KPS, mengetahui nilai overall equipment effectiveness (OEE) yang didasarkan pada faktor availability, performance dan rate of quality [7],[8]. Kedua, mengetahui faktorfaktor yang menjadi penyebab menurunnya efektivitas melalui pengukuran six big losses dan mengidentifikasikan faktorfaktor dominan dari faktor six big losses serta melakukan analisis terhadap faktor yang memberikan kontribusi paling besar menggunakan diagram pareto . Dan terakhir, memberikan rekomendasi dengan menggunakan diagram fishbone untuk mengatasi permasalahan utama dari faktor six big losses [9].

\section{Metode Penelitian}

Penelitian ini dilakukan di PT. KPS yang bergerak dibidang industri baja terpadu kualitas tinggi. Objek penelitian ini adalah adalah mesin cold leveller yang terdapat pada plate rolling department PT. KPS. Pengumpulan data dilakukan dengan dua cara [10],[11], yaitu survei langsung ke lapangan dan mengumpulkan data laporan harian mesin cold leveller PT. KPS selama 10 bulan yaitu bulan Februari 2018 hingga November 2018. Data yang digunakan berupa data historis mesin yang terdiri dari data downtime, data cacat produk, running time, urutan proses produksi, data perbaikan mesin dan jadwal perawatan. 


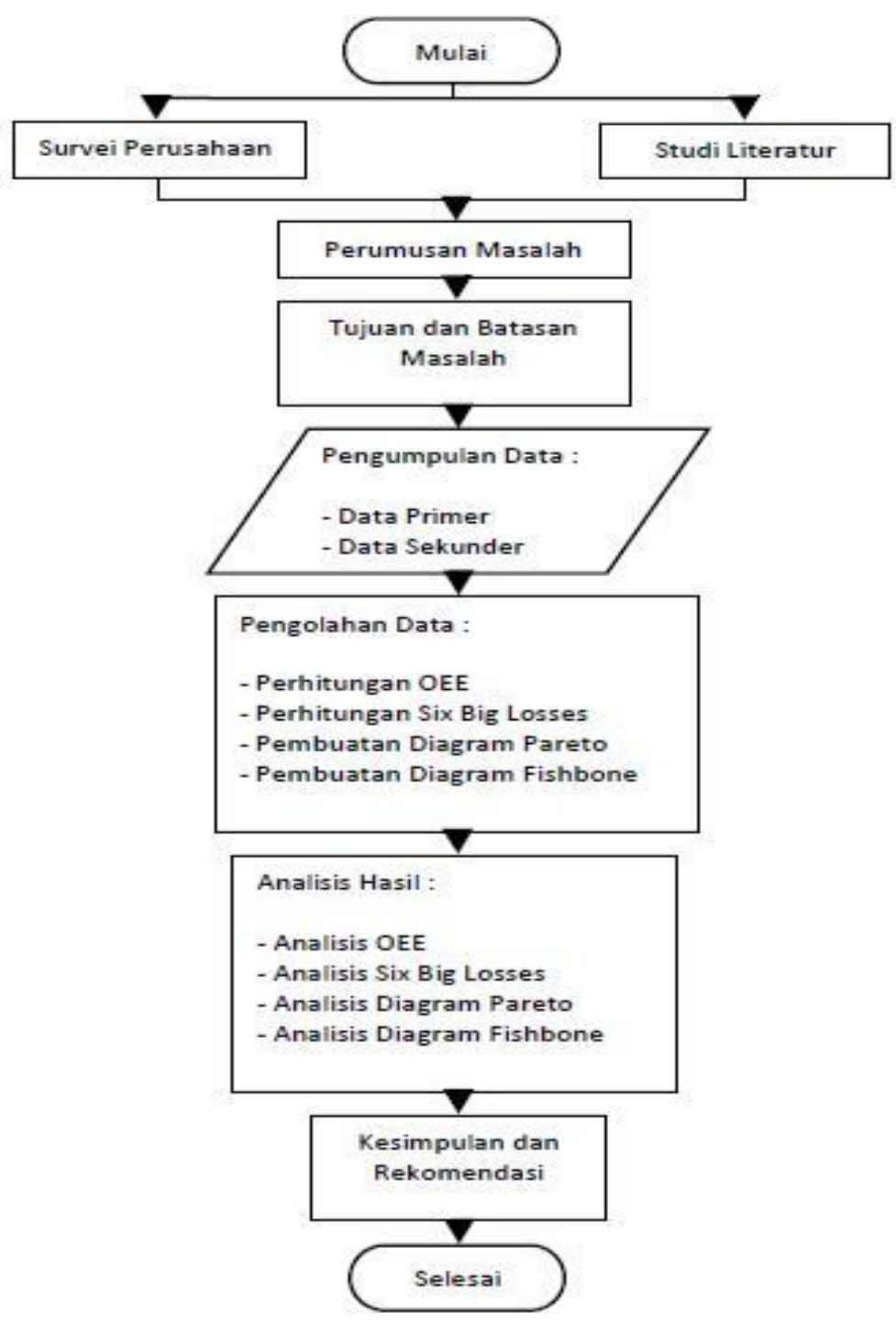

Gambar 1 Diagram Alir Penelitian

Menurut Nakajima, OEE merupakan nilai yang dinyatakan sebagai rasio antara output aktual dibagi output maksimum dari peralatan pada kondisi kinerja yang terbaik. Tujuan dari OEE adalah sebagai alat ukur performa dari suatu sistem maintenance. Dengan menggunakan metode ini maka dapat diketahui ketersediaan mesin atau peralatan (availability), efisiensi produksi (performance) dan kualitas output mesin atau peralatan. Untuk itu hubungan antara ketiga elemen produktifitas tersebut dapat dilihat pada rumus dibawah ini [12],[13] :

$$
\text { OEE }=\text { Availability } x \text { Performance } x \text { Quality }
$$

Availability adalah ketersediaan mesin atau peralatan yang merupakan perbandingan antara waktu operasi (operation time) terhadap waktu persiapan (loading time) dari suatu mesin atau peralatan. Maka availibility dapat dihitung sebagai berikut [12],[13] :

$$
\text { Availability }=\frac{\text { Available Time-Down Time }}{\text { Available } \text { Time }} \times 100 \%
$$

Performance adalah tolak ukur dari efisiensi suatu kinerja mesin menjalankan proses produksi. Perfomance rate merupakan hasil perkalian dari operating speed rate dengan net operating speed. Net 
operating speed berguna untuk menghitung menurunnya kecepatan produksi. Tiga faktor yang penting untuk menghitung peformance rate adalah ideal cycle time (waktu siklus ideal atau waktu standar), processed amount (jumlah produk yang diproses) dan operation time (waktu proses mesin). Maka performance dapat dihitung sebagai berikut [12],[13] :

$$
\text { Performance Rate }=\frac{\text { operatimg Speed Rate }}{\text { Net Operating Rate }} \times 100 \%
$$

Quality rate adalah perbandingan jumlah produk yang baik terhadap jumlah produk yang diproses. Jadi quality merupakan hasil perhitungan dengan faktor processed amount dan defect amount. Formula ini sangat membantu untuk mengungkapkan masalah kualitas proses produksi [12],[13].

$$
\text { Quality Rate }=\frac{\text { Processed amount }- \text { Defect amount }}{\text { Processed amount }} \times 100 \%
$$

Proses produksi tentunya mempunyai losses yang mempengaruhi keberhasilannya, losses tersebut oleh Nakajima di kelompokkan menjadi 6 besar yaitu [14]:

1. Equipment failure atau breakdown losses, kerugian ini terjadi dikarenakan peralatan mengalami kerusakan, tidak dapat digunakan dan memerlukan perbaikan atau penggantian. Kerugian ini diukur dengan seberapa lama waktu selama mengalami kerusakan hingga selesai diperbaiki [15].

2. Set up and adjustment time/losses, kerugian ini diakibatkan perubahan kondisi operasi, seperti dimulainya produksi atau dimulainya shift yang berbeda, perubahan produk dan perubahan kondisi operasi. Contohnya seperti pergantian peralatan, pergantian cetakan dan pergantian jig [15].

3. Idling and minor stoppages losses, merupakan kerugian yang disebabkan oleh berhentinya peralatan karena ada permasalahan sementara, seperti mesin terputus-putus (halting), macet (jamming) serta mesin menganggur (idling) [16].

4. Reduced speed losses, yaitu pengurangan kecepatan produksi dari kecepatan desain peralatan tersebut. Pengukuran kerugian ini dengan membandingkan kapasitas ideal dengan beban kerja aktual. Defect atau quality losses, Jika ouput produksi yang dihasilkan tidak memenuhi spesifikasi kualitas maka disebut defect atau quality lossess, yang terdiri dari dua hal berikut:

5. Rework and quality defect, kerugian ini terjadi karena terjadi kecacatan produk selama produksi. Produk yang tidak sesuai spesifikasi perlu dirework atau dibuat scrap. Diperlukan tenaga kerja untuk melakukan proses rework dan material yang diubah menjadi scrap juga merupakan kerugian bagi perusahaan [17].

6. Yield lossess, terjadi dikarenakan bahan baku terbuang. Kerugian ini dibagi menjadi dua, yaitu kerugian bahan baku akibat desain produk dan metode manufacturing serta kerugian penyesuaian karena cacat kualitas produk yang diproduksi pada awal proses produksi dan saat terjadi pergantian [18].

Setelah diketahui lossess yang dominan melalui diagram pareto maka selanjutnya dicari akar penyebab masalahdengan menggunakan diagram fishbone [19].

\section{Hasil dan Pembahasan}

Data jam kerja mesin cold leveller PT. KPS ditunjukkan pada Tabel 1 dan nilai OEE dari mesin cold leveller selama bulan Februari 2018 sampai November 2018 dapat dilihat pada Tabel 2 dengan rata-rata pencapaian OEE hanya sebesar $82 \%$. 
Tabel 1 Jam Kerja Mesin Cold Leveller

\begin{tabular}{|c|c|c|c|c|}
\hline No & Bulan & $\begin{array}{c}\text { Jumlah } \\
\text { Hari }\end{array}$ & $\begin{array}{c}\text { Jam Kerja } \\
\text { (jam) }\end{array}$ & $\begin{array}{c}\text { Jam Kerja } \\
\text { (menit) }\end{array}$ \\
\hline 1 & Februari & 28 & 672 & 40320 \\
\hline 2 & Maret & 31 & 744 & 44640 \\
\hline 3 & April & 30 & 720 & 43200 \\
\hline 4 & Mei & 31 & 744 & 44640 \\
\hline 5 & Juni & 30 & 720 & 43200 \\
\hline 6 & Juli & 31 & 744 & 44640 \\
\hline 7 & Agustus & 31 & 744 & 44640 \\
\hline 8 & September & 30 & 720 & 43200 \\
\hline 9 & Oktober & 31 & 744 & 44640 \\
\hline 10 & Nopember & 30 & 720 & 43200 \\
\hline
\end{tabular}

Tabel 2 Nilai OEE Mesin Cold Leveller

\begin{tabular}{|c|c|c|c|c|c|}
\hline No & Bulan & Availability & $\begin{array}{c}\text { Performance } \\
\text { Rate }\end{array}$ & $\begin{array}{c}\text { Quality } \\
\text { Rate }\end{array}$ & OEE \\
\hline 1 & Februari & $88 \%$ & $106 \%$ & $99 \%$ & $92 \%$ \\
\hline 2 & Maret & $96 \%$ & $67 \%$ & $98 \%$ & $63 \%$ \\
\hline 3 & April & $98 \%$ & $106 \%$ & $99 \%$ & $102 \%$ \\
\hline 4 & Mei & $89 \%$ & $86 \%$ & $99 \%$ & $76 \%$ \\
\hline 5 & Juni & $95 \%$ & $72 \%$ & $100 \%$ & $68 \%$ \\
\hline 6 & Juli & $97 \%$ & $59 \%$ & $100 \%$ & $57 \%$ \\
\hline 7 & Agustus & $93 \%$ & $75 \%$ & $99 \%$ & $69 \%$ \\
\hline 8 & September & $90 \%$ & $102 \%$ & $99 \%$ & $91 \%$ \\
\hline 9 & Oktober & $97 \%$ & $123 \%$ & $99 \%$ & $118 \%$ \\
\hline \multicolumn{5}{|c|}{} & \multicolumn{5}{|l|}{ Rata-rata } & \\
\hline
\end{tabular}

OEE

- OEE

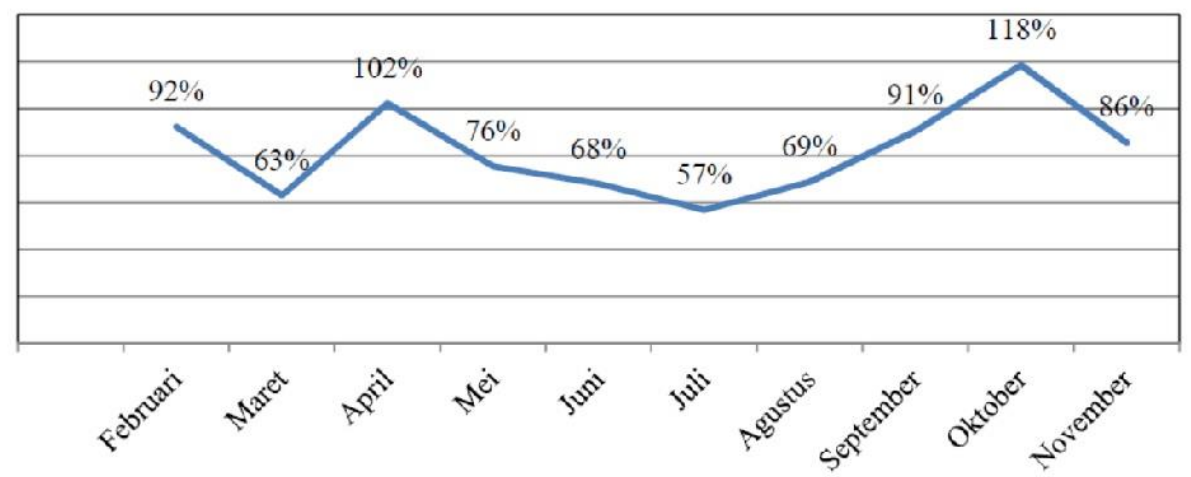

Gambar 2 Grafik Persentase OEE 
Setelah diperoleh nilai OEE, selanjutnya dilakukan proses identifikasi six big lossess selama bulan Februari 2018 sampai November 2018 yang dapat dilihat pada Tabel 3.

Tabel 3 Persentase Kumulatif Masing-Masing Losses

\begin{tabular}{|l|c|c|c|}
\hline \multicolumn{1}{|c|}{ Jenis Losses } & Rata-Rata & Persentase & Persentase Kumulatif \\
\hline $\begin{array}{l}\text { Equipment failure or breakdown } \\
\text { losses }\end{array}$ & $6,04 \%$ & $31,17 \%$ & $90,97 \%$ \\
\hline Set up and adjustment losses & $0,05 \%$ & $0,24 \%$ & $100,00 \%$ \\
\hline Iddling and minor stoppage losses & $0,78 \%$ & $4,04 \%$ & $99,76 \%$ \\
\hline Reduced speed losses & $11,59 \%$ & $59,80 \%$ & $59,80 \%$ \\
\hline Defect or quality losses & $0,92 \%$ & $4,75 \%$ & $95,72 \%$ \\
\hline Total & $19,38 \%$ & $100,00 \%$ & \\
\hline
\end{tabular}

Dengan melakukan analisis pareto terhadap seluruh jenis losses, akar permasalahan yang sesungguhnya dapat ditemui. Dari six big losses diatas dapat digambarkan diagram pareto [20](Gambar 3) yang memperlihatkan dengan jelas pengaruh six big losses tersebut terhadap efektivitas mesin cold leveller. Pada Gambar 3, terlihat bahwa reduced speed losses dan equipment failure losses merupakan faktor dominan yang menyebabkan rendahnya nilai OEE.

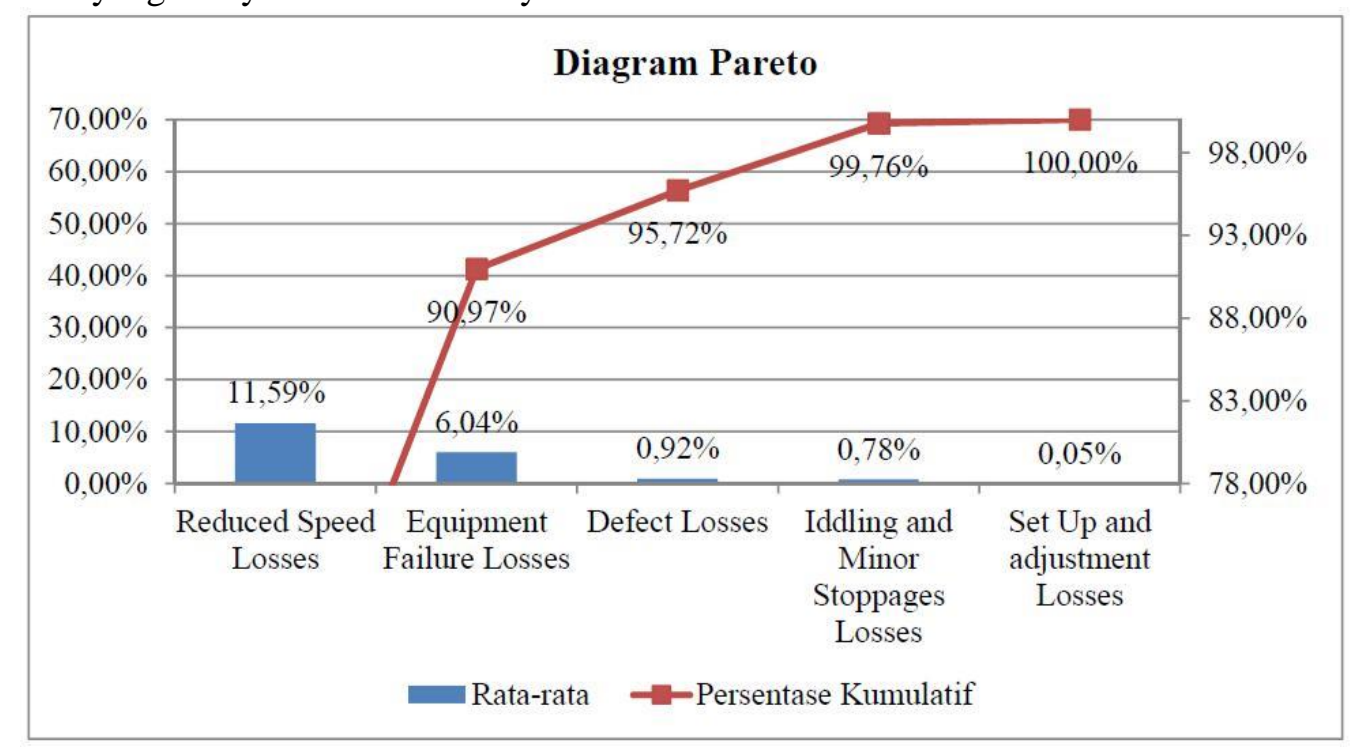

Gambar 3 Diagram Pareto

Analisis terhadap penyebab faktor-faktor six big losses yang mengakibatkan rendahnya efektivitas mesin dalam perhitungan OEE dilakukan dengan menggunakan diagram sebab akibat (fishbone diagram) [21],[22],[23]. Berdasarkan diagram pareto yang telah dibuat [24],[25],[20], faktor dominan yang berpengaruh terhadap besarnya produktivitas dan efisiensi mesin adalah reduced speed losses dan equipment failure losses. Setelah diketahui bahwa penyebab rendahnya nilai overall equipment effectiveness adalah reduced speed losses dan equipment failure losses, kemudian untuk mengetahui akar penyebabnya dengan menggunakan fishbone diagram. Faktor yang dianalisis dalam fishbone diagram adalah manusia atau man, mesin, metode, material, dan lingkungan kerja. Berikut adalah gambar dari fishbone diagram penyebab rendahnya nilai overall equipment effectiveness : 


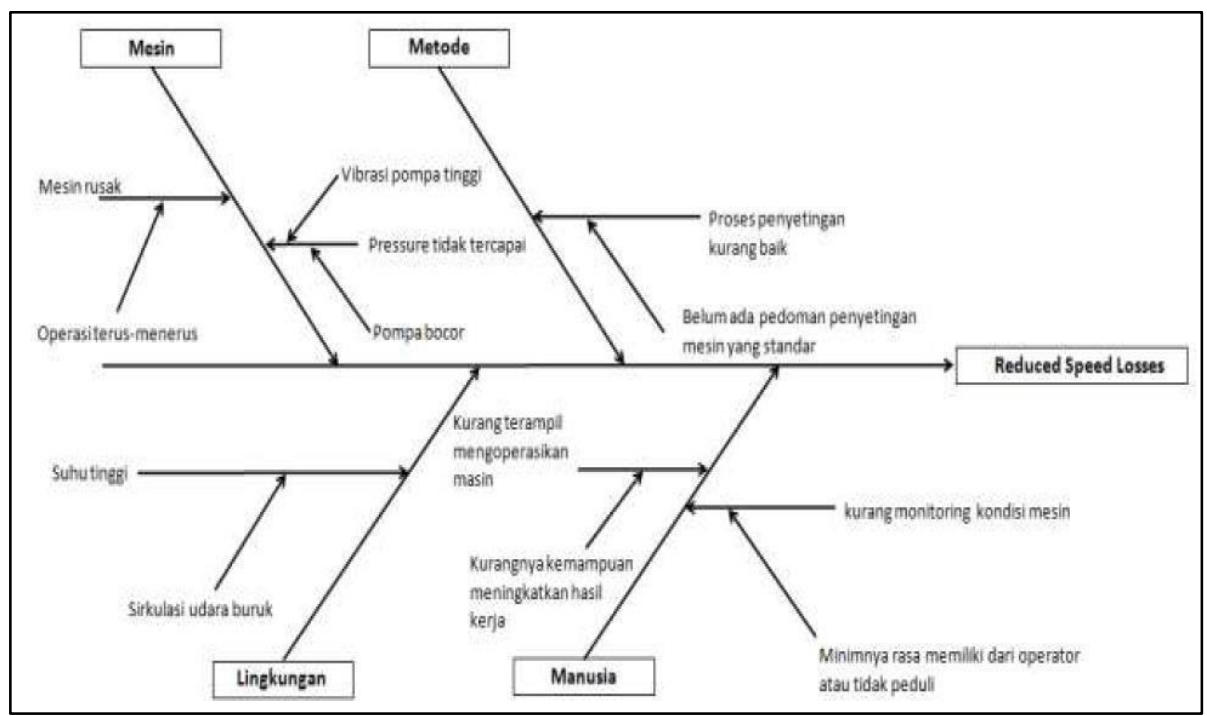

Gambar 4 Fishbone Equipment Failure Losses

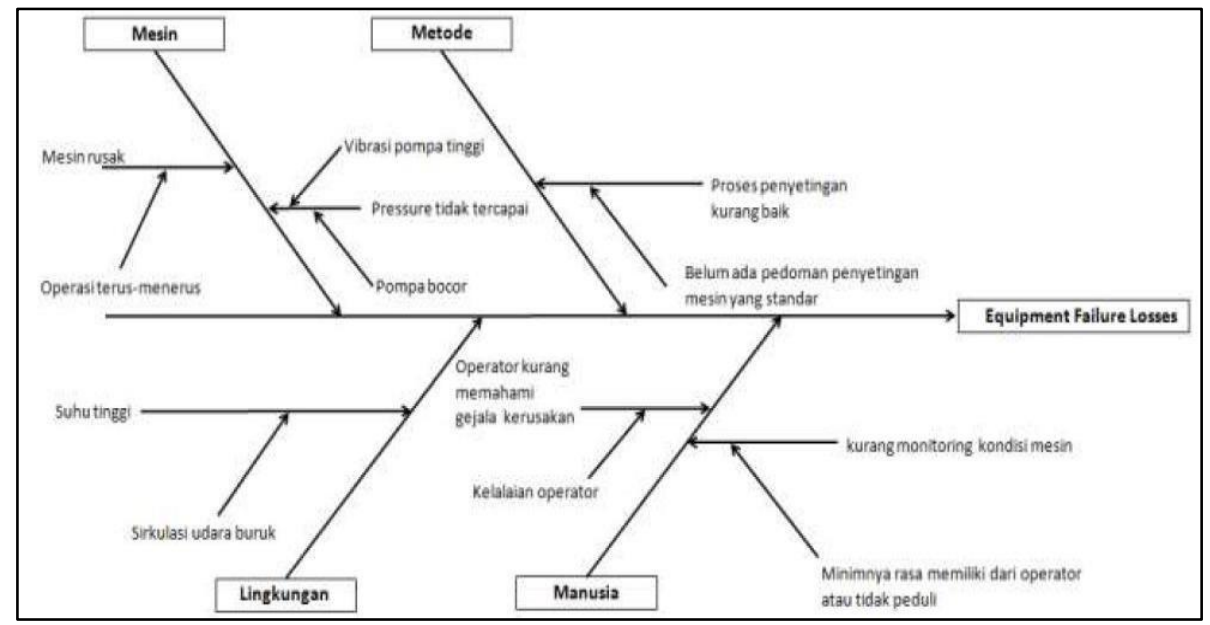

Gambar 5 Fishbone Equipment Failure Losses

Dari gambar diatas dapat diketahui bahwa terdapat 4 kategori penyebab rendahnya OEE [7],[26], yaitu sebagai berikut :

1. Manusia

Salah satu faktor yang menyebabkan tingginya reduced speed losses dan equipment failure lossesyaitu operator kurang terampil dalam mengoperasikan mesin dan operator kurang memahami gejala kerusakan mesin.

2. Mesin

Mesin Cold leveller beroperasi selama 24 jam dalam satu hari dan harus beroperasi terus menerus dalam satu hari membuat komponen yang ada pada mesin cepat mengalami keausan atau kerusakan.

3. Lingkungan

Faktor lingkungan juga dapat berpengaruh pada tingginya losses, suhu ruangan didalam pabrik cukup membuat operator kurang nyaman dalam bekerja. Dibeberapa tempat terdapat blower namun tetap kurang menjaga suhu ruangan yang nyaman untuk bekerja, selain itu suhu ruangan yang panas dapat membuat karet atau seal pada mesin cepat rusak sehingga menyebabkan mesin hidrolik sering bocor dan vibrasi pada pompa hidrolik tinggi. 
4. Metode

Metode maintenance yang digunakan saat ini adalah metode periodic maintenance.

Berdasarkan faktor-faktor diatas maka dirancang perbaikan sistem TPM berdasarkan 8 Pilar TPM dengan prioritas 3 pilar utama yaitu antonomous maintenance, quality maintenance dan training \& education [4],[12],[27],[6] :

1. Autonomous maintenance:

a. reset based level yaitu mengimplementasikan kegiatan maintenance harian oleh operator pada aktivitas pembersihan, inspeksi mesin dan pelumasan mesin.

b. menerapkan antonomous maintenance di setiap working station.

2. Quality maintenance:

a. melakukan evaluasi dan perbaikan terhadap kerusakan atas mutu dan kontrol performa mesin.

b. fokus pada kegiatan quality source dan quality assurance [28].

c. penerapan sistem preventive maintenance yang efektif dalam ketepatan waktu dan biaya.

d. mengimplementasikan pendeteksi kesalahan dini.

3. Training dan education :

a. gaps skill dan training need analysis

b. conduct training terkait materi khusus dan awareness training secara regular

c. verifikasi efektifitas terhadap kepatuhan penerapan

d. People dan skill matrix

\section{Kesimpulan}

Berdasarkan penelitian yang telah dilakukan, maka dapat ditarik kesimpulan sebagai berikut :

1. Besarnya rata-rata nilai OEE (Overall Equipment Effectiveness) adalah 82\%. Nilai ini masih dibawah standar yaitu $85 \%$ walaupun nilai availability dan quality rate cukup tinggi namun performance rate masih kurang sehingga nilai OEE tergolong rendah sehingga perlu adanya perbaikan untuk meningkatkan nilai OEE.

2. Jenis six big losses yang dominan menyebabkan rendahnya nilai OEE pada mesin cold leveller adalah reduced speed losses dan equipment failure losses. Reduced speed losses merupakan losses terbesar dari keseluruhan losses yang terjadi yaitu sebesar 11,59\% dan equipment failure losses berada di posisi kedua dengan nilai $6,04 \%$.

3. Tindakan perbaikan yang diusulkan adalah memprioritaskan 3 pilar utama TPM yaitu autonomous maintenance, quality maintenance, training dan education.

1. Antonomous maintenance:

a. reset based level yaitu mengimplementasikan kegiatan maintenance harian oleh operator pada aktivitas pembersihan, inspeksi mesin dan pelumasan mesin.

b. menerapkan antonomous maintenance \& operator di setiap working station.

2. Quality Maintenance :

a. melakukan evaluasi dan perbaikan terhadap kerusakan atas mutu dan kontrol performa mesin.

b. fokus pada kegiatan quality source dan quality assurance.

c. penerapan sistem preventive maintenance yang efektif dalam ketepatan waktu dan biaya.

d. mengimplementasikan pendeteksi kesalahan dini.

3. Training \& education:

a. gaps skill dan training need analysis

b. conduct training training terkait materi khusus dan awareness training secara regular

c. verifikasi efektifitas terhadap kepatuhan penerapan

d. people dan skill matrix. 


\section{Daftar Pustaka}

[1] O. V. Gaspersz and R. Qms-a, "Total Productive Maintenance ( TPM ): Bukan Sekedar Perbaikan Mesin."

[2] D. I. Rinawati and N. C. Dewi, "Analisis Penerapan Total Productive Maintenance (TPM) Menggunakan Overall Equipment Efectiveness (OEE) Dan Six Big Losses Pada Mesin Cavitec Di PT. Essentra Surabaya," Progr. Stud. Tek. Ind. Fak. Tek. Univ. Diponegoro, vol. Prosiding, pp. 21-26, 2014.

[3] U. Nurfaizah, H. Adianto, and H. Prassetiyo, "Rancangan Penerapan Total Productive Maintenance (TPM) Di Bagian Press II PT. XYZ,” Reka Integr., vol. 2, no. 1, 2014.

[4] B. Kho, "Eight Pilar Total Productive Maintenance," ilmumanajemenindustri.com, 2019. [Online]. Available: https://ilmumanajemenindustri.com/8-pilar-tpm-total-productivemaintenance/. [Accessed: 13-Jul-2019].

[5] E. Y. T. Adesta, H. A. Prabowo, and D. Agusman, "Evaluating 8 pillars of Total Productive Maintenance $(\{\mathrm{TPM}\})$ implementation and their contribution to manufacturing performance," \{IOP\} Conf. Ser. Mater. Sci. Eng., vol. 290, p. 12024, Jan. 2018.

[6] E. Yulian Triblas Adesta and H. Agung Prabowo, "Total Productive Maintenance (TPM) Implementation Based on Lean Manufacturing Tools in Indonesian Manufacturing Industries," Int. J. Eng. Technol., vol. 7, no. 3.7, p. 156, 2018.

[7] P. Amrih, "Overall Equipment Effectiveness," www.pitoyo.com, 1997. [Online]. Available: https://www.pitoyo.com/catatanpitoyo/index.php/oee/97-sejarah-oee. [Accessed: 13-Jul-2019].

[8] D. Wahjudi, S. Tjitro, R. Soeyono, J. Siwalankerto, and S. Indonesia, "Studi Kasus Peningkatan Overall Equipment Effectiveness ( Oee )," Univ. Stuttgart, 2009.

[9] M. M. Firmansyah, A. Susanty, and D. Puspitasari, "Analisis Overall Equipment Effectiveness dan Six Big Losses pada Mesin Pencelupan Benang (Studi Kasus PT. Pismatex Textile Industry)," Ind. Eng. Online J., vol. 4, no. 4, 2015.

[10] A. Maksum, "Pengumpulan data," J. Metod. pengumpulan data, 2012.

[11] Ali Maksum, "Data, Teknik Pengumpulan Data dan Instrumen Penelitian," J. Cakrawala Kependidikan, no. agustus, p. 107, 2012.

[12] D. H. Stamatis, The OEE primer: Understanding overall equipment effectiveness, reliability, and maintainability. 2017.

[13] Carlo Scodanibbio, Overall Equipment Effectiveness (OEE), no. January. Italia: scobbanibbio.com, 2009.

[14] S. Nakajima, Introduction to TPM: Total Productive Maintenance (Preventative Maintenance Series) By Seiichi Nakajima. Japanese, 2019.

[15] D. Agung, F. Debora, and H. H. Purba, "Increased Productivity of Injection Molding with Analysis of Overall Equipment Effectiveness ( OEE )," Int. J. Res. Eng. Sci. Manag., vol. 1, no. 12, pp. 1-7, 2018.

[16] A. Y. Tobe, D. Widhiyanuriyawan, and L. Yuliati, "The Integration of Overall Equipment Effectiveness (Oee) Method and Lean Manufacturing Concept To Improve Production Performance (Case Study: Fertilizer Producer)," J. Eng. Manag. Ind. Syst., vol. 5, no. 2, pp. 102-108, 2018.

[17] D. Alvira, Y. Helianty, and H. Prassetiyo, "Usulan Peningkatan Overall Equipment 
Effectiveness OEE) Pada Mesin Tapping Manual Dengan Meminimumkan Six Big Losses,” $J$. Itenas Bandung, vol. 03, no. 03, pp. 240-251, 2015.

[18] I. Nursanti and Y. Susanto, "Analisis Perhitungan Overall Equipment Effectiveness (Oee) Pada Mesin Packing Untuk Meningkatkan Nilai Availability Mesin," J. Ilm. Tek. Ind., vol. 13, no. 1, pp. 96-102, 2014.

[19] K. Ishii and B. Lee, "REVERSE FISHBONE DIAGRAM: A TOOL IN AID OF DESIGN FOR PRODUCT RETIREMENT," Mech. Eng., vol. 1, 1394.

[20] X. Blasco, J. M. Herrero, J. Sanchis, and M. Martínez, "A new graphical visualization of ndimensional Pareto front for decision-making in multiobjective optimization," Inf. Sci. (Ny)., vol. 178 , no. 20, pp. 3908-3924, Oct. 2008.

[21] S. Indonesia, "Analisis Akar Masalah dengan Fishbone Diagram," 1, 2016. [Online]. Available: http://shiftindonesia.com/analisa-akar-masalah-dengan-fishbone-diagram/.

[22] R. Hutagaol, "Analysis of the Implementation of Nursing Professional Values in Referral Hospitals Jakarta: Fishbone Analysis," Int. J. Nurs. Heal. Serv., vol. 2, no. 1, pp. 108-116, 2019.

[23] H. P. Bloch, "Root Cause Failure Analysis," in Petrochemical Machinery Insights, 2017.

[24] Sitesgoogle, "Kelola Kualitas," sites.google, 2016. [Online]. Available: https://sites.google.com/site/kelolakualitas/Diagram-Pareto.

[25] E. Zio and R. Bazzo, "Level Diagrams analysis of Pareto Front for multiobjective system redundancy allocation,” Reliab. Eng. Syst. Saf., vol. 96, no. 5, pp. 569-580, May 2011.

[26] S. Wahyudi, "Penerapan Overall Equipment Effectiveness ( Oee ) Dalam Implementasi Total Productive Maintenance ( TPM ) ( Studi Kasus di Pabrik Gula PT . 'Y' .)," vol. 3, no. 3, pp. 431-437, 2012.

[27] E. Y. T. Adesta, H. A. Prabowo, and D. Agusman, "Evaluating 8 pillars of Total Productive Maintenance (TPM) implementation and their contribution to manufacturing performance," IOP Conf. Ser. Mater. Sci. Eng., vol. 290, no. 1, pp. 0-8, 2018.

[28] "Introduction and certification of a quality assurance system : Helmut Ensslin. Quality Europe. Industrial Quality Assurance. 34th EOQ Annual Conference, Dublin, Ireland, 13 (1990)," Microelectron. Reliab., vol. 32, no. 1-2, p. 291, Jan. 1992. 